\title{
Carbon Stocks of Hardwood Floodplain Forests along the Middle Elbe: The Influence of Forest Age, Structure, Species, and Hydrological Conditions
}

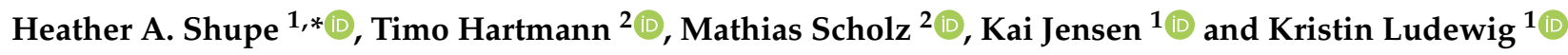 \\ 1 Applied Plant Ecology, Institute of Plant Sciences and Microbiology, Universität Hamburg, Ohnhorststraße 18, \\ 22609 Hamburg, Germany; kai.jensen@uni-hamburg.de (K.J.); Kristin.Ludewig@uni-hamburg.de (K.L.) \\ 2 Helmholtz-Centre for Environmental Research-UFZ, Department of Conservation Biology, Permoserstraße 15, \\ 04318 Leipzig, Germany; timo.hartmann@ufz.de (T.H.); mathias.scholz@ufz.de (M.S.) \\ * Correspondence: Heather.Alyson.Shupe@uni-hamburg.de; Tel.: +49-40-42816-388
}

Citation: Shupe, H.A.; Hartmann, T.; Scholz, M.; Jensen, K.; Ludewig, K. Carbon Stocks of Hardwood Floodplain Forests along the Middle Elbe: The Influence of Forest Age, Structure, Species, and Hydrological Conditions. Water 2021, 13, 670. https://doi.org/10.3390/w13050670

Academic Editor: Alenka Gaberščik

Received: 30 January 2021

Accepted: 25 February 2021

Published: 1 March 2021

Publisher's Note: MDPI stays neutral with regard to jurisdictional claims in published maps and institutional affiliations.

Copyright: (c) 2021 by the authors. Licensee MDPI, Basel, Switzerland. This article is an open access article distributed under the terms and conditions of the Creative Commons Attribution (CC BY) license (https:// creativecommons.org/licenses/by/ $4.0 /)$.

\begin{abstract}
Hardwood floodplain (HF) forests can store a considerable amount of carbon (C), and floodplains may be good candidates for reforestation to provide natural $\mathrm{C}$ sinks. In this study, we use nondestructive inventory methods to estimate the $C$ stocks of different tree species and $C$ pools within HF forests of varying age and structure and located at sites differing in hydrological conditions (low and high active floodplain, seepage water zone, tributaries). The study was carried out along the Elbe river (Germany). Average $C$ stocks for young plantations in the active floodplain were significantly lower $\left(50.2 \pm 10.8 \mathrm{SE} \mathrm{Mg} \mathrm{ha}^{-1}\right)$ than those of old dense $\left(140.6 \pm 11.6 \mathrm{SE} \mathrm{Mg} \mathrm{ha}{ }^{-1}\right)$ and old sparse forests $\left(180.4 \pm 26.6 \mathrm{SE} \mathrm{Mg} \mathrm{ha}^{-1}\right)$ with comparable hydrological conditions. C stocks of old dense forests did not significantly vary from old sparse forests. Additionally, $\mathrm{C}$ stocks of old forests did not significantly vary according to hydrological conditions. The highest amount of $\mathrm{C}$ was stored in Quercus robur for all hydrological conditions. Ulmus laevis stored the second-highest amount of $\mathrm{C}$ on the active floodplain. We conclude that sparse and dense forests as well as forests under different hydrological conditions provide the same $\mathrm{C}$ storage function.
\end{abstract}

Keywords: carbon stocks; hardwood floodplain forest; hydrological conditions; floodplain ecology

\section{Introduction}

Hardwood floodplain (HF) forests can store a considerable amount of carbon (C) in woody biomass and provide many ecological services such as climate regulation through long-term C storage [1-3]. Globally, HF forests have declined substantially during the last centuries, and in Germany, natural HF forests have been reduced to less than $1 \%$ of the active floodplain area [4-6]. The destruction of European HF forests began in the Middle Ages and continued with the expansion of agricultural land and the construction of dikes [7]. Only $10-20 \%$ of the former floodplains of the major river catchments in Germany are left, and these active floodplain areas are dominated by managed grasslands [5,6]. HF forests also grow on the seepage water zone behind the dike and on tributary floodplains, but they have different hydrological site conditions which may influence their function. Many of today's remnants of HF forests are patchy and sparse, and dense HF forests with successful natural regeneration are rare.

Land management which increases the $C$ storage of ecosystems is known to be a natural climate solution, and reforestation has garnered global attention as a climate change mitigation measure [8]. Global and regional initiatives such as the Bonn Challenge and ECCA30 have set targets to restore millions of hectares of degraded and deforested lands by 2030 [9]. To meet these targets, suitable locations for reforestation must be identified. Highly productive floodplains are good candidates for reforestation [3], where other ecosystem services such as habitat provisioning to increase biodiversity and flood risk reduction 
of agricultural lands could also be maximized by reforestation [10]. Many studies have identified positive effects of floodplain vegetation on flood risk reduction, concluding that floodplain vegetation reduces flood risks by increasing hydraulic resistance, reducing flow velocity, and reducing peak magnitude at the catchment outflow [11-13]. However, vegetation with high roughness can also potentially increase flood risks in upstream areas, and to what degree the roughness of vegetation affects flooding in different locations is still under debate [13]. Flow resistance may be influenced by forest age and density [14,15], and the ecosystem services and functions (i.e., $\mathrm{C}$ storage) of different forest ages and structures must therefore be quantified and assessed in parallel with other ecosystem services such as flood risk reduction to determine suitable floodplain management advice [16]. Reforestation of HF forests is also possible on the seepage water zone behind dikes and on the tributary floodplains, but it is not well known whether the $C$ storage function of these forests with different hydrological conditions is equal to the active floodplain of the main river channel.

The few available studies on $C$ stocks in HF forests report a wide range of $C$ stocks of the standing biomass (7.5-281 Mg ha ${ }^{-1}$ ) [2]. On the Danube floodplain in Austria, C stock in aboveground biomass of HF forests is highest $\left(281 \pm 59 \mathrm{Mg} \mathrm{ha}^{-1}\right)$ compared to softwood $\left(163 \pm 26 \mathrm{Mg} \mathrm{ha}^{-1}\right)$, cottonwood $\left(199 \pm 29 \mathrm{Mg} \mathrm{ha}^{-1}\right)$, and reforestations $\left(35 \pm 17 \mathrm{Mg} \mathrm{ha}^{-1}\right)$ [17]. Interestingly, in another study for the same area of the Danube floodplain, much lower aboveground C stocks $\left(123 \pm 26 \mathrm{Mg} \mathrm{ha}^{-1}\right)$ were reported for mixed hardwood and softwood riparian forests [18]. While differences between inventory methods may have contributed to the wide range of $C$ stock estimates, other site-specific conditions such as forest age and structure as well as hydrological and other abiotic conditions and species composition could also play a role here.

Stand structure and forest age affects the growth and yield of trees [19] and the C storage function of forests [20]. Management of forest stands, i.e., timber extraction, understory livestock grazing, and the clearance of deadwood and thinning of trees to enhance the growth and dimensions of a few harvestable trees, is a long-standing practice in Europe [21-23]. In Germany, timber extraction occurs in a majority of floodplain forests, and only a few near-natural stands remain [24]. The few remaining patches of dense forests which are multilayered and exhibit a well-developed shrub layer and overstory are contrasted with sparse forests which lack a well-developed shrub layer. Sparse and dense forests most likely represent differences in former and current management. Both sparse and dense forest are present on the active floodplain, but it is not known how C stocks differ according to these forest structures.

Trees in HF forests must withstand large hydrological fluctuations resulting in hypoxic or anoxic soils during flooding events and drought in dry periods. Annual flooding duration of $\mathrm{HF}$ forests on the active floodplain is related to elevation, with relatively low-lying $\mathrm{HF}$ forests subject to longer periods of hypoxia and those at higher elevations more prone to drought. Soil texture affects the water holding capacity and plant available water of the soil, with loamy soil able to hold more water than sandy soil during dry periods [25]. In lowland floodplains, soils are commonly loamy in low-elevated and sandy in high-elevated sites [26], where plant available water may therefore be additionally reduced during dry periods. HF forests are typically dominated by Fraxinus, Ulmus, and Quercus taxa [27]. Quercus robur and Ulmus laevis are two characteristic tree species for European HF forests which are adapted to cope with flooding and reduced soil oxygen availability through the development of adventitious roots and hypertrophied lenticels $[28,29]$. Additionally, the capacity to regulate stomatal conductance and long tap roots allow Q. robur to survive moderate drought stress. However, Q. robur is also prone to hydraulic failure due to vessel cavitation resulting in increased mortality under prolonged drought conditions [30]. $U$. laevis thrives in damp soils and is highly vulnerable to vessel cavitation and mortality as a result of drought stress [30,31]. It is not well known how much these adaptations affect the growth of trees in different hydrological conditions, and how this in turn influences $C$ stocks of HF forests on the active floodplain, the seepage water zone and tributaries. 
In this study, we aim to answer (a) how C storage of HF forests develops with age, (b) whether sparse forests fulfill the same $C$ storage function as dense forests, (c) how C storage of HF forests differs between typical hydrological conditions and (d) how $\mathrm{C}$ storage differs by taxon under different hydrological conditions.

\section{Materials and Methods}

\subsection{Study Area and Forest Types}

The study area is a part of the UNESCO Biosphere Reserve River Landscape Elbe and spans approximately $100 \mathrm{~km}$ along the lower Middle Elbe river within the German states Saxony-Anhalt, Brandenburg, and Lower Saxony (Figure 1). The study area is located within the central European temperate climate region. The Lenzen weather station $\left(53.08^{\circ} \mathrm{N}, 11.48^{\circ} \mathrm{E}\right)$ records a mean annual precipitation of $615 \mathrm{~mm}$ and a mean annual temperature of $9.3^{\circ} \mathrm{C}$ for 1981-2010 [32]. Characteristic soils of the Elbe floodplain include Gleysols, Fluvisols, and Cambisols [26].

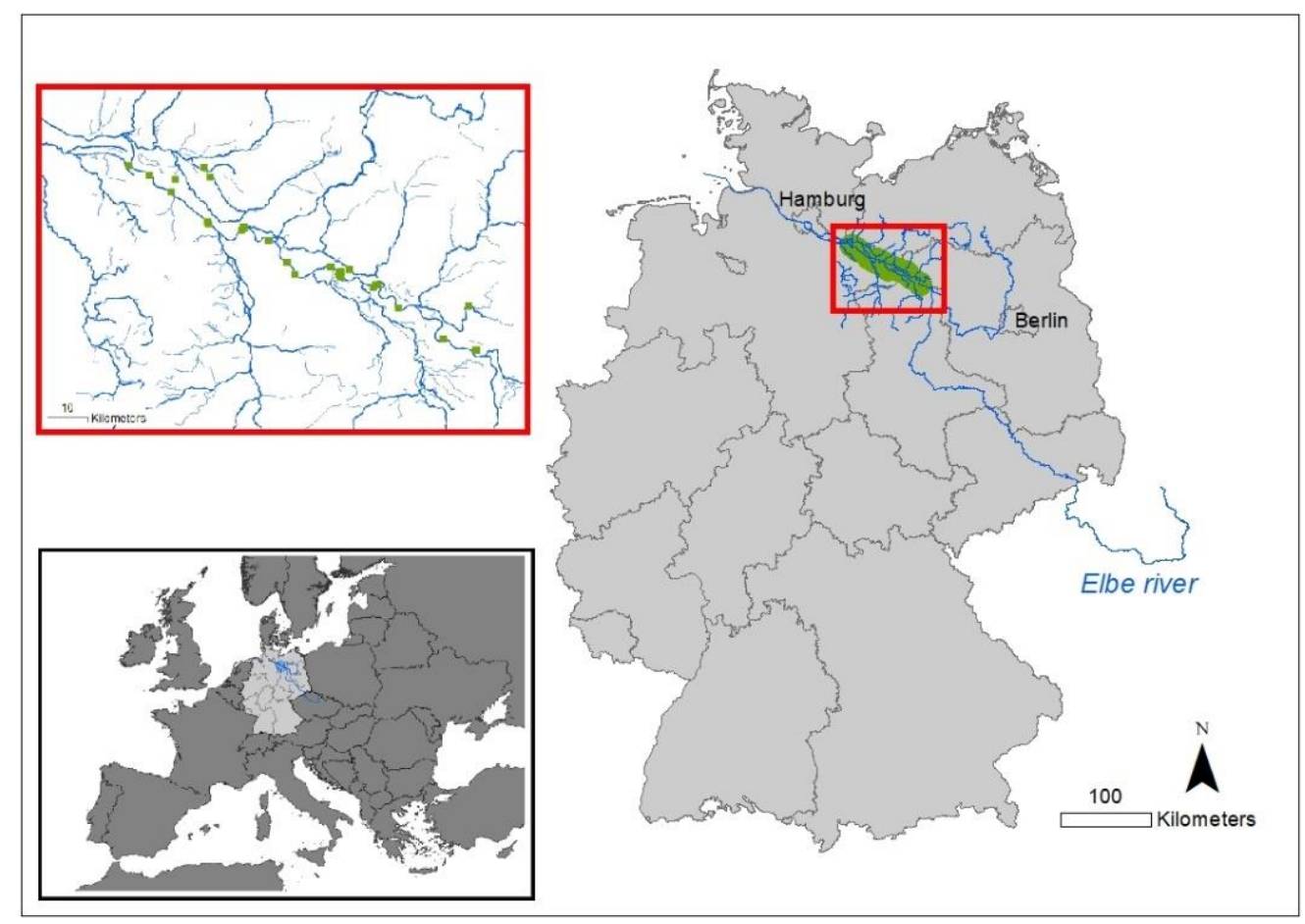

Figure 1. Map of the study area along the Middle Elbe river, Germany. The red box outlines the area which spans approximately $100 \mathrm{~km}$ along the Elbe river and the green dots represent the locations of each $2500 \mathrm{~km}^{2}$ plot in the different studied forest types.

The UNESCO Biosphere Reserve River Landscape Elbe is used as a model system for anthropogenically altered European floodplains. With a history of diking, deforestation and agriculture on the active floodplain, todays' HF forests represent only small remnants of the former contiguous ecosystem type. On the active floodplain confined by dikes, HF forests are more frequently flooded on the lower sites and less frequently flooded on the higher sites. Flooding events mainly occur on the active floodplain [33] after snow melt during winter and spring and after intense rain events during summer. The duration of flooding is related to elevation on the active floodplain.

Typical species in HF forests, also referred to as mixed riparian forests (NATURA 2000 Code 91F0), include pedunculate oak (Quercus robur), European white, field, and wych elm (Ulmus laevis, Ulmus minor, and Ulmus glabra), European hornbeam (Carpinus betula), and European ash (Fraxinus excelsior). Typical understory vegetation includes Crataegus monogyna, Sambucus nigra, and Cornus sanguinea. 


\subsection{Study Sites and Sampling}

This study investigates six different forest types ( $n=5$ per type). In total, 30 plots $\left(2500 \mathrm{~m}^{2}\right.$ each) were studied. A sketch of the study design is shown in Figure 2 and site characteristics for each forest type are presented in Table 1.

The effect of forest age and structure on the $\mathrm{C}$ storage of HF forests was studied for 15 plots located on the low active floodplain only. Here, five replicate plots of young plantations, old sparse, and old dense HF forests were sampled. The five young plantations are composed of woody species (mainly $Q$. robur and $U$. laevis) which were actively planted on a mix of former grasslands and forests. Dense forests are characterized as multilayered forests with a well-developed overstory and shrub layer, while sparse forests lack the well-developed shrub layer. The age of the young plantations ranged from 18-27 years while the old forests ranged from 80-200 years.

HF forests are found behind the dikes in the seepage water zone of the fossil floodplain and at floodplains of the tributaries. In this study, the possible effects of hydrological conditions on $\mathrm{C}$ storage of old dense HF forests were analyzed by sampling five replicate plots of these four forest types (low active floodplain, high active floodplain, seepage water zone, tributary; Figure 2). Hydrological conditions for high and low plots on the active floodplain were selected based on the average number of days the sites were flooded per year: a categorical mean of $0-5$ days of flooding for high plots and greater than five days of flooding for the low plots. Flooding duration was estimated using a 35 year mean from 1990-2016 with a 1-dimensional model that integrates data from various databases [34].

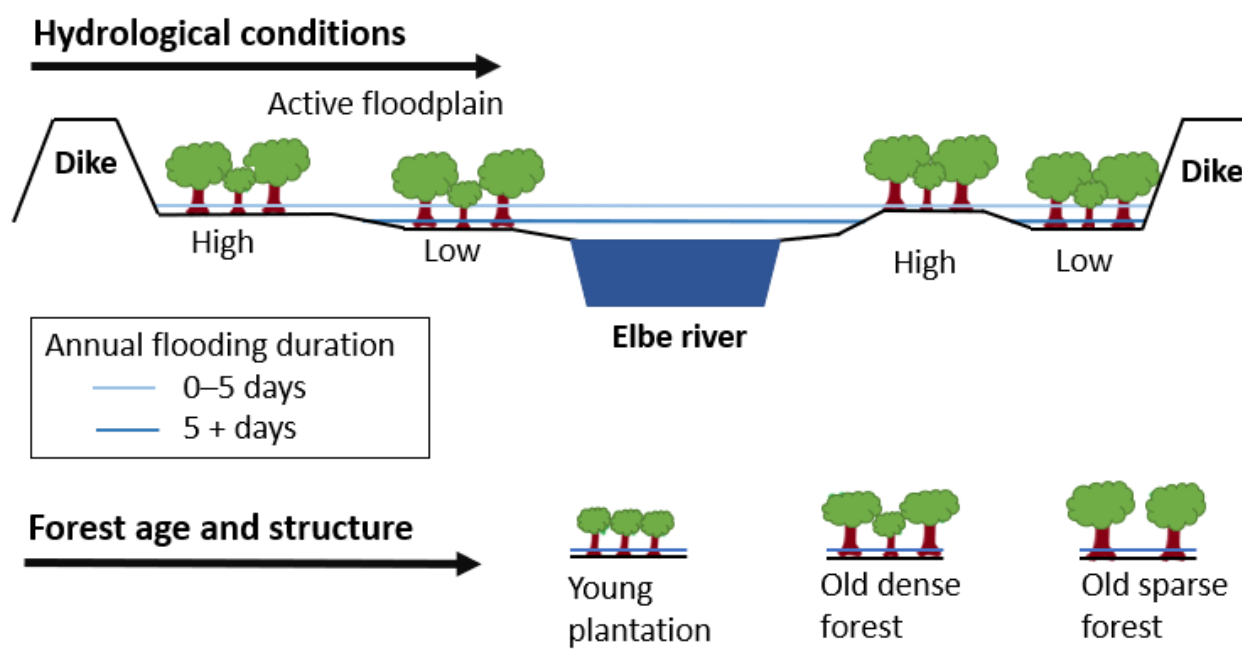

Figure 2. Study design showing old dense HF forests with different hydrological conditions (high active floodplain, low active floodplain, seepage water zone, and tributary) and HF forests with different ages and structure (young plantation, old sparse, and old dense) on the low active floodplain. Softwood floodplain forests and other land cover and ecosystem types are not represented in this sketch. 
Table 1. Characteristics of each studied forest type showing minimum (min), maximum (max), and mean values with standard deviation (SD). Each forest type has a sample size of five replicate plots. $\mathrm{DBH}=$ diameter at breast height. $\mathrm{x}$ indicates a lack of data related to the spatial limitations of the flooding duration model.

\begin{tabular}{|c|c|c|c|c|c|c|c|c|c|c|c|c|}
\hline & \multicolumn{2}{|c|}{$\begin{array}{c}\text { Low Active } \\
\text { Floodplain, Young }\end{array}$} & \multicolumn{2}{|c|}{$\begin{array}{c}\text { Low Active } \\
\text { Floodplain, Old } \\
\text { Dense }\end{array}$} & \multicolumn{2}{|c|}{$\begin{array}{c}\text { Low Active } \\
\text { Floodplain, Old } \\
\text { Sparse }\end{array}$} & \multicolumn{2}{|c|}{$\begin{array}{l}\text { High Active } \\
\text { Floodplain }\end{array}$} & \multicolumn{2}{|c|}{$\begin{array}{c}\text { Seepage Water } \\
\text { Zone }\end{array}$} & \multicolumn{2}{|c|}{ Tributary } \\
\hline & $\begin{array}{l}\text { Min } \\
\text { Max }\end{array}$ & $\begin{array}{l}\text { Mean } \\
\pm S D\end{array}$ & $\begin{array}{l}\text { Min } \\
\text { Max }\end{array}$ & $\begin{array}{l}\text { Mean } \\
\pm S D\end{array}$ & $\begin{array}{l}\text { Min } \\
\text { Max }\end{array}$ & $\begin{array}{l}\text { Mean } \\
\pm S D\end{array}$ & $\begin{array}{l}\text { Min } \\
\text { Max }\end{array}$ & $\begin{array}{l}\text { Mean } \\
\pm S D\end{array}$ & $\begin{array}{l}\text { Min } \\
\text { Max }\end{array}$ & $\begin{array}{l}\text { Mean } \\
\pm S D\end{array}$ & $\begin{array}{l}\text { Min } \\
\text { Max }\end{array}$ & $\begin{array}{l}\text { Mean } \\
\pm \text { SD }\end{array}$ \\
\hline $\begin{array}{c}\text { Forest } \\
\text { age } \\
\text { (years) }\end{array}$ & $\begin{array}{l}18 \\
27\end{array}$ & $23 \pm 4$ & $\begin{array}{l}104 \\
200\end{array}$ & $\begin{array}{c}141 \pm \\
36\end{array}$ & $\begin{array}{l}129 \\
167\end{array}$ & $\begin{array}{c}144 \pm \\
14\end{array}$ & $\begin{array}{l}108 \\
186\end{array}$ & $\begin{array}{c}134 \pm \\
33\end{array}$ & $\begin{array}{c}81 \\
185\end{array}$ & $\begin{array}{c}128 \pm \\
39\end{array}$ & $\begin{array}{c}82 \\
170\end{array}$ & $\begin{array}{c}130 \pm \\
37\end{array}$ \\
\hline $\begin{array}{c}\text { Basal } \\
\text { area } \\
\left(\mathrm{m}^{2}\right. \\
\left.\mathrm{ha}^{-1}\right)\end{array}$ & $\begin{array}{l}12 \\
30\end{array}$ & $22 \pm 7$ & $\begin{array}{l}26 \\
36\end{array}$ & $32 \pm 4$ & $\begin{array}{l}29 \\
52\end{array}$ & $38 \pm 10$ & $\begin{array}{l}27 \\
45\end{array}$ & $36 \pm 8$ & $\begin{array}{l}29 \\
43\end{array}$ & $35 \pm 6$ & $\begin{array}{l}27 \\
44\end{array}$ & $36 \pm 7$ \\
\hline $\begin{array}{l}\text { Tree } \\
\text { count } \\
(\text { trees } \\
\mathrm{ha}^{-1} \text { ) }\end{array}$ & $\begin{array}{c}728 \\
1576\end{array}$ & $\begin{array}{c}1245 \pm \\
346\end{array}$ & $\begin{array}{l}181 \\
496\end{array}$ & $\begin{array}{c}291 \pm \\
121\end{array}$ & $\begin{array}{c}75 \\
160\end{array}$ & $\begin{array}{c}123 \pm \\
40\end{array}$ & $\begin{array}{l}192 \\
325\end{array}$ & $\begin{array}{c}248 \pm \\
55\end{array}$ & $\begin{array}{l}235 \\
464\end{array}$ & $\begin{array}{c}357 \pm \\
100\end{array}$ & $\begin{array}{l}331 \\
763\end{array}$ & $\begin{array}{c}531 \pm \\
186\end{array}$ \\
\hline $\begin{array}{l}\text { Mean } \\
\text { tree } \\
\text { height } \\
(\mathrm{m})\end{array}$ & $\begin{array}{c}8 \\
14\end{array}$ & $11 \pm 3$ & $\begin{array}{l}11 \\
20\end{array}$ & $15 \pm 3$ & $\begin{array}{l}13 \\
26\end{array}$ & $22 \pm 5$ & $\begin{array}{l}13 \\
21\end{array}$ & $16 \pm 4$ & $\begin{array}{l}12 \\
26\end{array}$ & $18 \pm 6$ & $\begin{array}{l}14 \\
20\end{array}$ & $17 \pm 3$ \\
\hline $\begin{array}{l}\text { Mean } \\
\text { tree } \\
\text { DBH } \\
(\mathrm{cm})\end{array}$ & $\begin{array}{l}11 \\
16\end{array}$ & $14 \pm 2$ & $\begin{array}{l}20 \\
39\end{array}$ & $32 \pm 7$ & $\begin{array}{l}43 \\
85\end{array}$ & $60 \pm 16$ & $\begin{array}{l}29 \\
39\end{array}$ & $36 \pm 5$ & $\begin{array}{l}20 \\
45\end{array}$ & $31 \pm 11$ & $\begin{array}{l}20 \\
30\end{array}$ & $25 \pm 4$ \\
\hline $\begin{array}{l}\text { Tree } \\
\text { species } \\
\text { rich- } \\
\text { ness }\end{array}$ & $\begin{array}{l}1 \\
5\end{array}$ & $3 \pm 2$ & $\begin{array}{l}2 \\
3\end{array}$ & $2 \pm 1$ & $\begin{array}{l}1 \\
3\end{array}$ & $2 \pm 1$ & $\begin{array}{l}2 \\
5\end{array}$ & $3 \pm 1$ & $\begin{array}{l}3 \\
8\end{array}$ & $5 \pm 2$ & $\begin{array}{c}3 \\
10\end{array}$ & $5 \pm 3$ \\
\hline $\begin{array}{l}\text { Flooding } \\
\text { dura- } \\
\text { tion } \\
\left(\text { days }^{-1} \text { ) }\right.\end{array}$ & $\begin{array}{c}6 \\
86\end{array}$ & $34 \pm 28$ & $\begin{array}{l}11 \\
59\end{array}$ & $36 \pm 18$ & $\begin{array}{c}9 \\
33\end{array}$ & $22 \pm 9$ & $\begin{array}{l}0 \\
9\end{array}$ & $4 \pm 3$ & $x$ & $x$ & $x$ & $x$ \\
\hline
\end{tabular}

\subsection{Carbon Stock Estimations}

Individual C stocks of trees, shrubs, deadwood, and litter were analyzed in the winter months between January and April of 2018 and 2019. The total C stocks per plot were estimated by averaging the summed values for large trees, shrubs, standing dead trees, downed woody debris, and leaf litter. These values were then scaled to $\mathrm{Mg} \mathrm{ha}^{-1}$.

\subsubsection{Trees}

For quantifying $C$ stocks of trees, four $625 \mathrm{~m}^{2}$ square nested plots (quadrants) were delineated within each of the 30 plots. Within three quadrants for old forests and two quadrants for young plantations, the diameter at breast height (DBH; $1.3 \mathrm{~m}$ above ground level) of all trees $\geq 5 \mathrm{~cm}$ was measured using a standard diameter tape. Within the same quadrants, the height $(\mathrm{H})$ of all trees with a $\mathrm{DBH} \geq 5 \mathrm{~cm}$ were measured with a Vertex Laser Geo (Haglöf, Sweden). The species identity of each measured tree was recorded.

Based on the measured variables $\mathrm{H}$ and $\mathrm{DBH}$, individual tree stem volumes were calculated with species-specific allometric equations (Table A1 in Appendix A) [35]. Aboveground tree biomass was calculated by multiplying estimated tree stem volume by speciesspecific average wood density (Table A2 in Appendix A) taken from the Global Wood Density Database [36]. Finally, a C content (CC) fraction of 0.47 was applied to estimate aboveground tree $C$ stock [37]. To estimate the $C$ stocks of tree roots, a root: shoot ratio of 0.3 was applied to the aboveground tree $\mathrm{C}$ stock [38]. 


\subsubsection{Shrubs}

All shrubs with a DBH $\geq 5 \mathrm{~cm}$ were inventoried using the line intersect transect method. Each quadrant chosen for the tree inventory was transected diagonally, and the $\mathrm{DBH}$ and $\mathrm{H}$ of any shrub crossing $1 \mathrm{~m}$ from each side of the transect was measured. The allometric volume equation, biomass factor and C factor for Corylus (Table A1) was used for all shrubs and the values were scaled to $\mathrm{Mg} \mathrm{ha}^{-1}$. The roots of the shrubs were estimated using a root: shoot factor of 0.4 [37].

\subsubsection{Deadwood}

The $\mathrm{C}$ stock of deadwood was measured following the methodologies and density reduction factors proposed by the United Nations to measure C stocks [37]. Two deadwood pools were measured: large standing dead trees (SDT) and downed woody debris (DWD).

To measure SDT's, the same allometric equations were used as for the estimates of $C$ stocks of large trees, which were then multiplied by density reduction factors depending on the state of decay (sound $=1$; intermediate $=0.8$; rotten $=0.45$ ). Unlike in the United Nations guidelines [37], if a tree was leaning or newly fallen and lay completely within the study plot, it was included in the SDT pool. The roots of SDTs were measured the same as the live trees, with a root: shoot ratio of 0.3 .

Lying downed woody debris (DWD) was measured using transect lines diagonally crossing three quadrants for every plot (with a total length of $106 \mathrm{~m}$ per plot). All deadwood with a diameter $\geq 5 \mathrm{~cm}$ crossing the transect lines were measured horizontally and vertically at the point of intersect and the state of decay was recorded. Trees already accounted for in the SDT pool were omitted. Equation (1) was used to estimate the volume of DWD [39]. DWD volume estimates were then multiplied by 0.5 to obtain DWD biomass, density reduction factors depending on the state of decay, and finally by 0.5 to estimate C content.

$$
\hat{X}_{j}=\frac{\pi^{2}}{8 L_{j}} \sum_{i=1}^{N}\left(\frac{d_{1 i}+d_{2 i}}{2}\right)^{2}
$$

Equation (1) measures the volume of DWD $(\hat{X})$ in $\mathrm{m}^{3} \mathrm{ha}^{-1}$ for the individual sample plots $(j) . L_{j}$ is the horizontal length of the transect lines, while $d_{1 i}$ and $d_{2 i}$ are the horizontal and vertical diameter measurements (in $\mathrm{cm}$ ) of individual pieces of dead wood intersected along the transect.

\subsubsection{Litter}

The winter stock of leaf litter was estimated from February to March in 2019. The litter was measured in winter, because the plots are mainly dominated by oak trees, which do not abscise their leaves until late winter to early spring. Within each of the three studied quadrants, a $1 \mathrm{~m}^{2}$ quadrat frame was randomly placed along the diagonal transect and the dry weight of leaf litter was measured. Subsamples of fresh litter were brought to the lab and air dried until constant weight. The dry: wet weight ratio was applied to the field values, and the average quadrant values were taken as plot values. The biomass values were multiplied by 0.37 to estimate $C$ stock [37].

\subsection{Forest Ages}

Forest ages were estimated using annual tree ring measurements [40]. Tree cores were taken from four dominant $Q$. robur trees per plot using a $5 \mathrm{~mm}$ Mora increment borer. Singular relic trees with an outlying DBH from the other dominant trees from the same plot were not sampled. The surface of each core was carefully scraped with a razor blade to increase the visibility of the tree ring vessel structure. A microscope connected to a LINTAB ${ }^{\mathrm{TM}} 5$ measuring table and the TSAP-Win ${ }^{\mathrm{TM}}$ software program (RINNTECH, Heidelberg, Germany) were used to measure tree rings and establish tree ages. When the pith was not present, concentric circles were used to estimate missing rings [41]. 


\subsection{Statistical Analyses}

The $C$ stock data were tested for normality by Shapiro-Wilk test $(p>0.05)$ and a visual inspection of Q-Q plots, box plots, and histograms. Nonparametric independent-samples Kruskall-Wallis Tests with pairwise comparisons were conducted to examine the differences in $C$ stock for each $C$ pool according to forest age and structure and for the forests with different hydrological conditions. Different curve estimation models with forest type as the independent variable and total $C$ stocks as the dependent variable were assessed for best fit. Additionally, a univariate general linear model (GLM) was used to compare $C$ stocks of old, dense forests with different hydrological conditions. The dependent variable was $C$ stocks while the covariate was estimated forest age. Regression curve estimation models were explored to evaluate the best fit relationship between forest age and C stock. All tests were performed using SPSS version 26 (IBM Corp. 2019, Armonk, New York, NY, USA).

\section{Results}

\subsection{Carbon Stocks Related to Forest Age and Structure}

On the low active floodplain, the total $C$ stock of young plantations was $50.2 \pm$ 10.8 SE Mg ha ${ }^{-1}$ and thus significantly lower $(\mathrm{H}=10.5, p=0.005, \mathrm{df}=2)$ than that of old sparse $\left(180.4 \pm 26.6 \mathrm{SE} \mathrm{Mg} \mathrm{ha}{ }^{-1}\right)$ and of old dense forests $\left(140.6 \pm 11.6 \mathrm{SE} \mathrm{Mg} \mathrm{ha}{ }^{-1}\right)$. Pairwise comparisons found no significant difference between old sparse and old dense forests. Young plantations had significantly less $C$ stock in the tree pool than old dense or sparse forests $(\mathrm{H}=10.5, p=0.005, \mathrm{df}=2)$. Young plantations also had significantly less DWD than old dense forests $(\mathrm{H}=7.4, p=0.009, \mathrm{df}=1)$. No other significant differences comparing $C$ pools between different forest types on the low active floodplain were found. Overall, the most $C$ was stored in the tree $C$ pool than in any other pool (Figure 3, Table A3), and the SE of the tree pool was commonly larger than the stock estimated for other $C$ pools. A positive logarithmic relationship $\left(\mathrm{r}^{2}=0.741, p<0.001\right)$ was found between forest age and C stock (Figure 4).

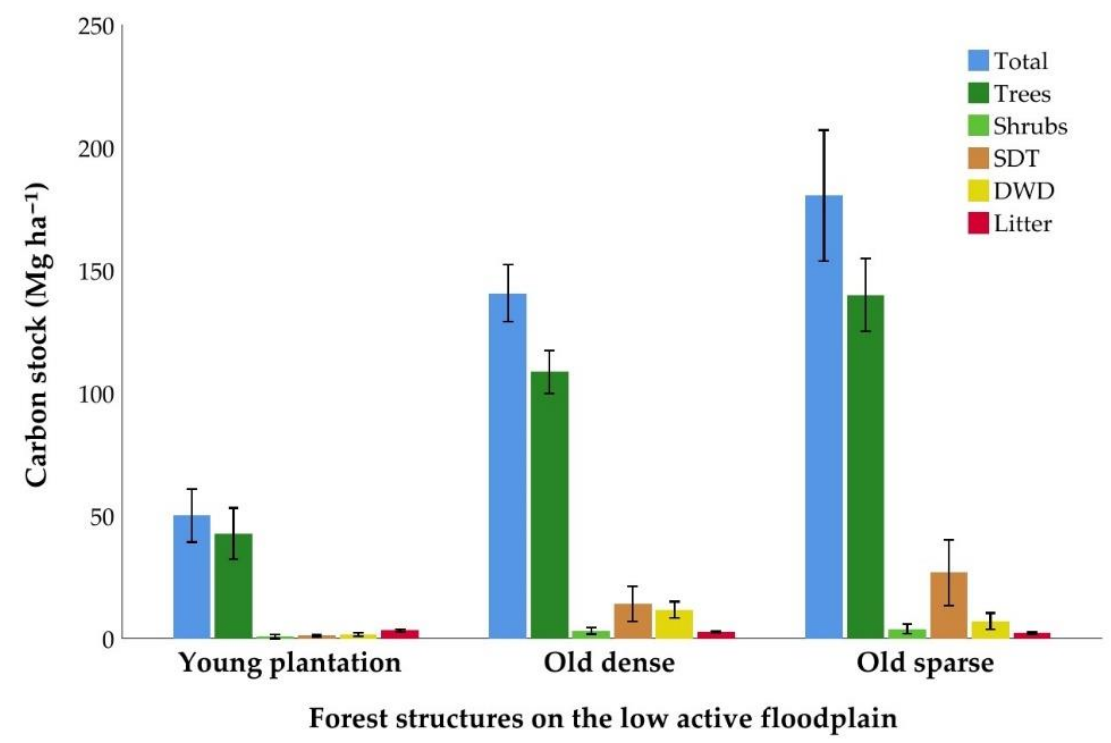

Figure 3. Carbon stocks in $\mathrm{Mg} \mathrm{ha}^{-1}$ of hardwood forests with different ages and structures on the low active floodplain (mean $\pm \mathrm{SE}, n=5$ ). Carbon pools include trees, shrubs, standing dead trees (SDT), downed woody debris (DWD), and leaf litter. 


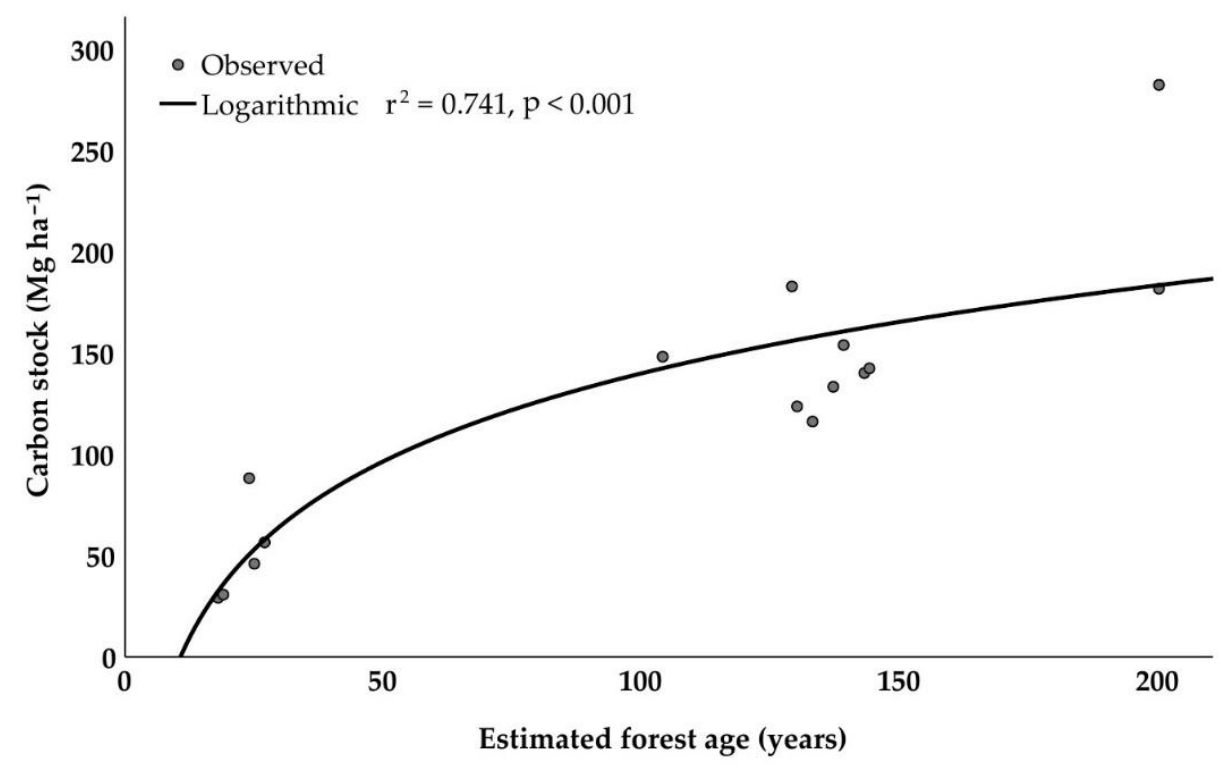

Figure 4. Carbon stocks in $\mathrm{Mg} \mathrm{ha}^{-1}$ of young plantations, old dense, and old sparse hardwood forests on the low active floodplain are plotted against estimated forest age in years. A logarithmic fit curve with the output of the regression is included. Carbon stocks include trees, shrubs, standing dead trees (SDT), downed woody debris (DWD), and leaf litter.

\subsection{Stocks of Old HF Forests under Different Hydrological Conditions}

$C$ stocks of old dense forests under different hydrological conditions ranged from $140.5 \pm 11.6$ (low active floodplain) to $163.5 \pm 8.3 \mathrm{SE} \mathrm{Mg} \mathrm{ha}^{-1}$ (high active floodplain) (Figure 5, Table A4). Kruskall-Wallis tests revealed that there were no significant differences between the total $C$ stock or any other $C$ pool of old dense forests with different hydrological conditions. The GLM revealed that the covariate, forest age, was not significantly related to $\mathrm{C}$ stock, $\mathrm{F}_{1,15}=0.72, p>0.05, \mathrm{r}=0.41$. There was also no significant effect of hydrological conditions on $\mathrm{C}$ stocks after controlling for forest age, $\mathrm{F}_{3,26}=0.54, p>0.05$, partial $\eta^{2}=0.10$.

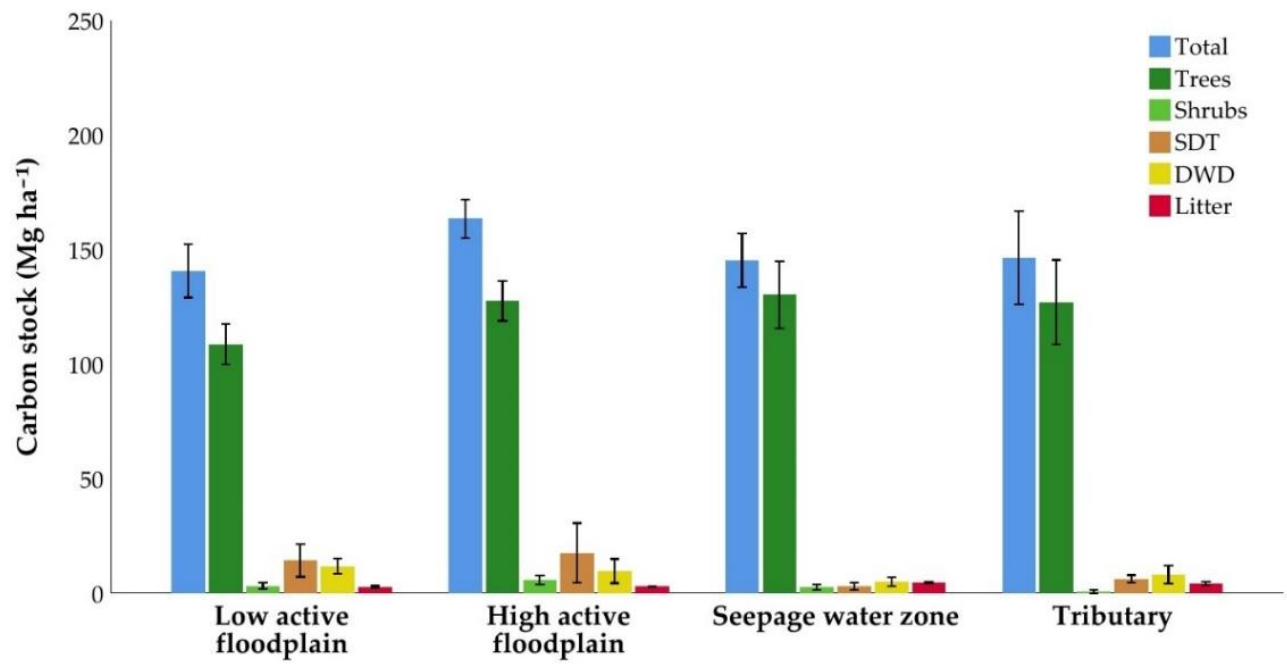

Old hardwood forests with different hydrological conditions

Figure 5. Carbon stocks in $\mathrm{Mg} \mathrm{ha}^{-1}$ of dense hardwood forests with different hydrological conditions (mean $\pm \mathrm{SE}, n=5$ ). Carbon pools include trees, shrubs, standing dead trees (SDT), downed woody debris (DWD), and leaf litter. 


\subsection{Stocks by Species}

Q. robur stored more $C$ than any other species in all hydrological conditions (Figure 6). On the active floodplain, Ulmus spp. stored the second highest amount of $\mathrm{C}$, whereas in the seepage water zone and on tributary floodplains, Ulmus spp. were rare and C. betulus stored the second highest amount of $\mathrm{C}$.

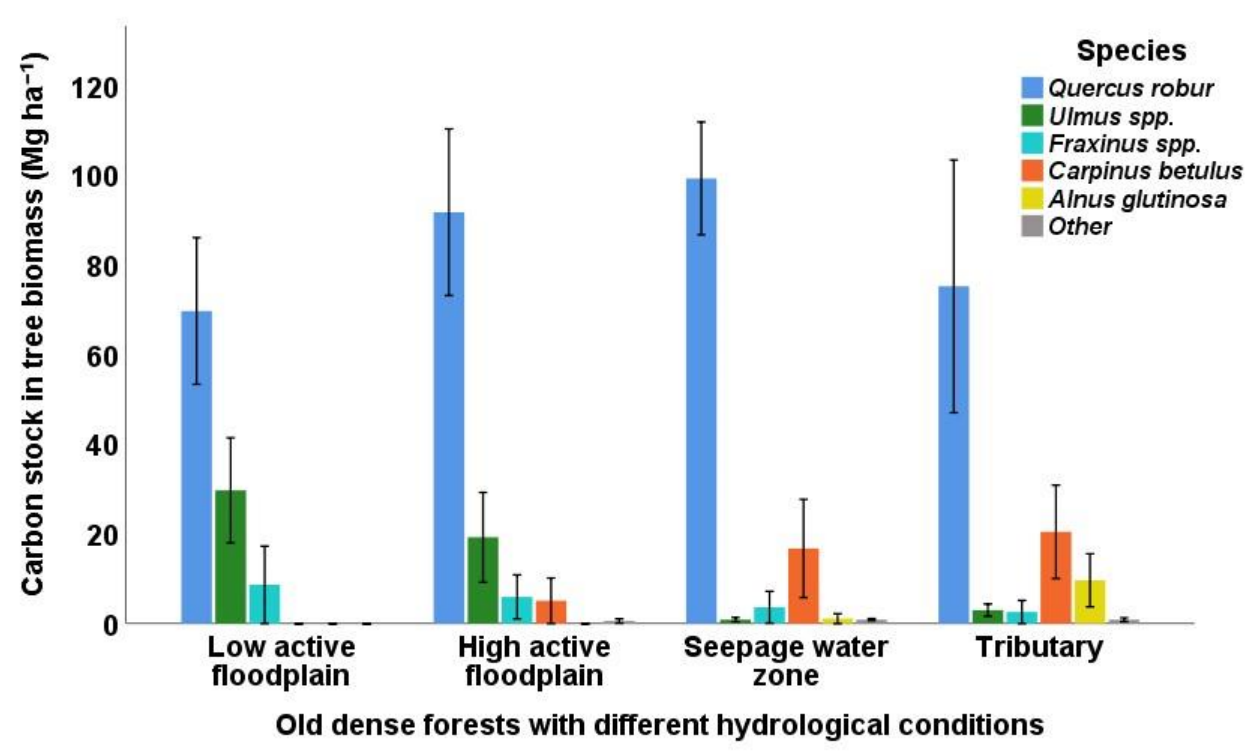

Figure 6. Carbon stock of large trees in $\mathrm{Mg} \mathrm{ha}^{-1}$ including above- and below-ground biomass by tree species (mean $\pm \mathrm{SE}, n=5$ ). Other tree taxa include Acer, Corylus, Fagus, Picea, Pinus, Populus, Prunus, Salix, Sorbus, and Tilia spp.

\section{Discussion}

C stocks positively developed with age, with young plantations storing less $C$ than old forests. This finding supports research in the floodplains of the Danube, where young reforestations also showed significantly lower $C$ stocks than mature HF forests [17]. Many years are required for young plantations to mature and provide the same ecosystem function as old forests, but from the projected path of the logarithmic age curve, the increase in $\mathrm{C}$ stock is greatest in the first fifty years, before the stock slowly begins to taper as the forest matures. This implies that the annual rate at which the young plantations store $\mathrm{C}$, or the $\mathrm{C}$ sequestration rate, is larger than that of old forests. The age curve had one major outlier, where the total estimated $\mathrm{C}$ stock was $282.4 \mathrm{Mg} \mathrm{ha}^{-1}$. This outlier forest was characterized as sparse, had the highest live tree stock (193.7 Mg ha-1), and had the highest proportion of $U$. laevis trees with large dimensions compared to other studied plots. This forest also had a significantly higher deadwood stock $\left(80.7 \mathrm{Mg} \mathrm{ha}^{-1}\right)$ than any other plot, with large fallen trees and SDTs left to naturally decompose. In most of the other old forest plots, deadwood may have been removed either by management or flooding disturbance. This rare outlier of a forest with ample deadwood suggests that the removal of deadwood decreases the $\mathrm{C}$ storage function of $\mathrm{HF}$ forests. However, because this is one outlier, more studies should be conducted specifically looking at the potential reduction in C stocks as a consequence of deadwood removal on the floodplains.

On the low active floodplain, sparse forests stored equally as much $\mathrm{C}$ as dense forests. While some studies find that thinning of floodplain forests can increase C stocks [42], this study suggests that the overall $C$ stock of naturally dense forests are equal to sparse forests. If the only purpose of reforestation is to maximize $C$ storage, then either forest structure would be an appropriate land management target. However, suitable land management decisions rely on the assessment of multiple ecosystem services [16] and must consider potential risks and the preference of local stakeholders. For example, how the different structures contribute to or alleviate flooding should also be quantified and used 
in the assessment to determine proper floodplain management. The potentially higher roughness of dense forests may increase or decrease flood protection, depending on the location along the river. While flood risk can be reduced downstream from a forest with high roughness through the reduction of flow velocity and peak magnitude at the catchment outflow [11-13], the flood risk upstream from the forest could be increased by the backwater effect [13]. Suitable locations for reforestation of either dense or sparse forests is therefore also dependent on the surrounding land use, and considerations should be made to maximize the benefits of reforestation while minimizing potential risks.

The total $\mathrm{C}$ stocks and all $\mathrm{C}$ pools of old dense HF forests with different hydrological conditions did not significantly differ between each other, which indicates that the $C$ storage function of the HF forests is equal. This finding supports the results of Rieger et al. [18], who observed no significant difference between $C$ stocks of HF forests on the active floodplain and HF forests behind dikes in the seepage water zone. Trees contributed the greatest to the total C stock, and the equal C stocks implies that the trees are well adapted to the different hydrological conditions. Although the dike severs the connection between the forests on the seepage water zone from the flood pulse and the nutrients that come with it [43], the trees still grow at a seemingly equal rate. To verify this, quantification of tree growth at an annual scale is needed. Additional research is also needed to assess the effects of climate change on tree vitality and productivity on different elevations of the active floodplain, the seepage water zone, and tributaries. Climate change models project increased temperatures, precipitation, and river discharge at the Elbe $[44,45]$, with increasing drought conditions in spring and summer and increased precipitation in autumn and winter [46]. There is some evidence that increased flood frequency may reduce drought effects on the active floodplain [47], but these benefits may not be as pronounced in the seepage water zone behind dikes. If the flooding events occur in winter, drought conditions under high spring and summer temperatures may lead to tree mortality, which will greatly alter the distribution of $\mathrm{C}$ within pools, from $\mathrm{C}$-fixing live trees to $\mathrm{C}$-releasing dead trees. The finding that the $C$ storage function of old hardwood forests is nearly equal on the low and high active floodplain, the seepage water zone, and tributaries reveals that all of these sites are potentially suitable for reforestation considering the past climatic conditions, but this may not be the case considering future climate change. Additionally, the other ecosystem services must now be quantified for these forests and stakeholder preferences taken into consideration to determine suitable land management decisions.

Our C stock estimates of $50.2 \pm 10.8 \mathrm{SE} \mathrm{Mg} \mathrm{ha}^{-1}$ for young plantations, $140.6 \pm$ 11.6 SE Mg ha ${ }^{-1}$ for old dense forests, and 180.4 $\pm 26.6 \mathrm{SE} \mathrm{Mg} \mathrm{ha}^{-1}$ for old sparse forests are within the 7.5-281 Mg ha ${ }^{-1}$ range of previously reviewed HF forests [2] and are similar to upland forests in Germany. Generally, the C storage in German forests is reported to be $120-190 \mathrm{Mg} \mathrm{ha}^{-1}$, depending on age class and tree species [48]. Quercus petraea forests in Northern Germany have an estimated C stock of $107.82 \pm 7.27 \mathrm{Mg} \mathrm{ha}^{-1}$ in aboveground live tree biomass and $9.35 \pm 6.51 \mathrm{Mg} \mathrm{ha}^{-1}$ in deadwood [49]. We estimated a $\mathrm{C}$ stock in aboveground tree biomass of $33 \pm 17.9 \mathrm{SE} \mathrm{Mg} \mathrm{ha}{ }^{-1}$ for young plantations, $83.6 \pm 15.1 \mathrm{SE} \mathrm{Mg} \mathrm{ha}^{-1}$ for old dense forests, and 107.6 $\pm 25.5 \mathrm{SE} \mathrm{Mg} \mathrm{ha}^{-1}$ for old sparse forests. Our C stock estimate for aboveground trees not including roots in old sparse forests is therefore almost identical to the estimate for naturally developed upland forests dominated by $Q$. petraea. Our deadwood estimates for old sparse forests; however, are much higher $\left(26 \pm 13.3 \mathrm{Mg} \mathrm{ha}^{-1}\right.$ for SDTs with an additional $7.2 \pm 3.3 \mathrm{Mg} \mathrm{ha}^{-1}$ for DWD). In another study of different forest types in Germany, the average $C$ stocks in aboveground and belowground biomass, deadwood and soils are reported to be $224 \mathrm{Mg} \mathrm{ha}^{-1}$ [50]. It is reported that $46 \%$ of $C$ is stored in the aboveground and belowground biomass and $1 \%$ of $\mathrm{C}$ is stored in deadwood, which would mean a $\mathrm{C}$ stock of $105 \mathrm{Mg} \mathrm{ha}^{-1}$ in trees and deadwood. This estimate is one third less than in our studied HF forests. The tree pool C stocks calculated in our study are lower than the estimated $281 \pm 59 \mathrm{Mg} \mathrm{ha}^{-1}$ for HF forests by the Danube river [17]. The large difference between $C$ stocks estimated along the Danube and those estimated here may be attributed to abiotic and climatic differences, 
management, forest structures such as number of tree stems, or methodological differences in estimating $C$ stocks. The HF forests along the Danube had a mean tree count of $590 \pm 80$, while the old forests studied here had a mean tree count ranging from $123 \pm 40$ to $531 \pm 186$. However, tree count is not a good indicator for determining $C$ stocks, as shown by young plantations which have a much larger tree count than old forests, but a lower overall $C$ stock. Additionally, a major setback in making accurate comparisons between studies reporting on $\mathrm{C}$ stocks of forests is the absence of a universally applied field inventory and $C$ calculation method. There are proposed guidelines, such as the UNFCCC methods [37]; however, there are various national inventories [51] as well as research papers [17,48-50,52,53], which use different field measurements and computational methods to estimate $C$ stocks. Various allometric equations are available, and the choice of the equations can greatly impact the estimated $C$ stock values. Additionally, many old trees such as oaks and elms become hollow as they mature, and the allometric equations do not take into account this reduction in biomass [54], which may result in an over-estimation of $\mathrm{C}$ stock. Although allometric equations provide a non-destructive way of measuring C stocks, there can be large variations depending on the selected equations, which adds great uncertainties to the estimated C distribution in different forest ecosystems worldwide [55].

Q. robur had a dominating presence in all hydrological conditions compared to other taxa, which may be a consequence of the species' drought and flood tolerance [28] or the fact that forest managers in the past mainly preferred to plant and foster oaks for quality timber harvesting and to provide animal fodder and tanning agents [56]. Today, planting campaigns that include a diversity of species are recommended to increase resilience against biotic stressors and variability in abiotic conditions [57], as well as to enhance productivity and C storage $[58,59]$. Monoculture planting campaigns should be avoided to minimize pathogens and insect attacks [60]. This is especially true in the middle Elbe region, where outbreaks of oak processionary moth (Thaumetopoea processionea) are especially prevalent in plantations with high oak densities. Therefore, although $Q$. robur is a suitable tree species for reforestation under all hydrological conditions, other species should be interspersed. Many elms (mainly U. laevis) were found on the active floodplain, while very few elms were growing in the seepage water zone or along the tributaries. Although the results may be interpreted in a way that the hydrological conditions of the seepage water zone are not suitable for elms, the lack of elms behind the dike could also be a consequence of management and the preference of foresters to foster oaks. Compared to oaks and elms, very few ash trees (F. excelsior) were observed, except for one plot that had mostly non-native green ash (F. pennsylvanica). Although ash dieback caused by the fungus Hymenoscyphus fraxineus could be a reason for the low F. excelsior numbers [61], ash is well adapted to thrive on floodplains but not able to resist this fungal infestation at present, and therefore reforestation of ash may not be suitable. C. betulus was numerous in the seepage water zone and tributaries, while the species' presence on the active floodplain was only apparent on the high elevated sites with lower annual flooding duration. This is most likely a consequence of the lower flood tolerance of $C$. betulus, which is not listed as typical species in the NATURA 2000 classification for riparian mixed forests. The exchange of $C$. betulus for $U$. laevis as the second most dominating species in the HF forests on the seepage water zone and tributaries may therefore be a consequence of the different hydrological conditions.

\section{Conclusions}

C stocks developed positively with age and the $C$ storage function of old forests did not significantly vary with forest structure on the low active floodplain or according to different hydrological conditions. Old forests on the low active floodplain, the high active floodplain, the seepage water zone, and tributaries fulfill the same ecosystem function of $\mathrm{C}$ storage and the locations are therefore at first glance equally suitable for reforestation campaigns. However, $\mathrm{C}$ storage is only one ecosystem service among many that should be quantified and evaluated to provide decisive and suitable land management advice. 
Additionally, the influence of climate change should also be considered. Q. robur is a good candidate for reforestations at all hydrological situations and should be accompanied by other suitable species such as $U$. laevis in all hydrological conditions and C. betulus in less frequently flooded conditions. F. excelsior is at present not a good candidate for reforestation because of the high risk of dieback.

Author Contributions: Conceptualization, H.A.S., M.S., K.J. and K.L.; Data curation, H.A.S.; Formal analysis, H.A.S.; Funding acquisition, K.J., M.S. and K.L.; Investigation, H.A.S.; Methodology, H.A.S., T.H., M.S. and K.L.; Project administration, K.L.; Resources, K.J.; Software, H.A.S.; Supervision, K.J. and K.L.; Validation, H.A.S., K.J. and K.L.; Visualization, H.A.S.; Writing—original draft, H.A.S.; Writing-review \& editing, H.A.S., T.H., M.S., K.J. and K.L. All authors have read and agreed to the published version of the manuscript.

Funding: This research was conducted within the interdisciplinary project MediAN (Mechanismen der Ökosystemdienstleistungen von Hartholz-Auenwäldern: Wissenschaftliche Analyse sowie Optimierung durch Naturschutzmanagement). This research was funded by the Bundesministerium für Bildung und Forschung (BMBF 01LC1601A).

Institutional Review Board Statement: Not applicable.

Informed Consent Statement: Not applicable.

Data Availability Statement: The data presented in this study are available on request from the corresponding author. The data are not publicly available due to privacy issues.

Acknowledgments: We would like to thank the landowners who participated in this study and the Biosphere reserve Niedersächsische Elbtalaue and Brandenburg Flusslandschaft Elbe with special thanks to Hans-Jürgen Kelm and Torsten Hennig. Thanks to soil scientists Adrian Heger and Lizeth Vásconez for the soil type analysis. Many thanks are also given to field and lab assistants Lilli Hamm and Fernanda Chavez, as well as to all other MediAN colleagues.

Conflicts of Interest: The authors declare no conflict of interest. The funders had no role in the design of the study; in the collection, analyses, or interpretation of data; in the writing of the manuscript, or in the decision to publish the results.

\section{Appendix A}

Table A1. Tree stem volume equations for all species inventoried in the Middle Elbe study area are shown, taken from Zianis et. al., 2005 (Appendix C) [35]. The country where the equation originates from and the units for volume (V), diameter at breast height $(\mathrm{D})$, and the height $(\mathrm{H})$ of individual trees are shown.

\begin{tabular}{|c|c|c|c|c|c|c|c|c|c|c|c|}
\hline \multirow[t]{2}{*}{$\begin{array}{c}\text { Tree } \\
\text { Species }\end{array}$} & & \multicolumn{3}{|c|}{ Unit } & \multirow[t]{2}{*}{ Equation } & \multicolumn{6}{|c|}{ Parameters } \\
\hline & & $\mathbf{V}$ & $\mathbf{D}$ & $\mathbf{H}$ & & $\mathbf{a}$ & $\mathbf{b}$ & c & d & e & $\mathbf{f}$ \\
\hline Acer spp. & NT & $\mathrm{dm}^{3}$ & $\mathrm{~cm}$ & $\mathrm{~m}$ & $\mathrm{D}^{\mathrm{a}} \cdot \mathrm{H}^{\mathrm{b}} \cdot \exp (\mathrm{c})$ & 1.89756 & 0.97716 & -2.94253 & & & \\
\hline $\begin{array}{l}\text { Alnus } \\
\text { glutinosa }\end{array}$ & NT & $\mathrm{dm}^{3}$ & $\mathrm{~cm}$ & $\mathrm{~m}$ & $\mathrm{D}^{\mathrm{a}} \cdot \mathrm{H}^{\mathrm{b}} \cdot \exp (\mathrm{c})$ & 1.85749 & 0.88675 & -2.5222 & & & \\
\hline $\begin{array}{l}\text { Betula } \\
\text { pendula }\end{array}$ & NT & $\mathrm{dm}^{3}$ & $\mathrm{~cm}$ & $\mathrm{~m}$ & $\mathrm{D}^{\mathrm{a}} \cdot \mathrm{H}^{\mathrm{b}} \cdot \exp (\mathrm{c})$ & 1.8906 & 0.26595 & -1.07055 & & & \\
\hline $\begin{array}{l}\text { Carpinus } \\
\text { spp. }\end{array}$ & NT & $\mathrm{dm}^{3}$ & $\mathrm{~mm}$ & $\mathrm{~m}$ & $\mathrm{a} \cdot \mathrm{D}^{(\mathrm{b}+\mathrm{c})} \cdot \mathrm{H}^{\mathrm{d}}$ & 0.00021491 & 2.258957614 & 0.001411006 & 0.60291075 & & \\
\hline $\begin{array}{l}\text { Corylus } \\
\text { avellana }\end{array}$ & NO & $\mathrm{dm}^{3}$ & $\mathrm{~cm}$ & $\mathrm{~m}$ & $\begin{array}{c}\mathrm{a}+\mathrm{b} \cdot \mathrm{D}^{2}+\mathrm{c} \cdot \mathrm{D}^{2} \cdot \mathrm{H}+ \\
\mathrm{d} \cdot \mathrm{D} \cdot \mathrm{H}^{2}+\mathrm{e} \cdot \mathrm{H}^{2}\end{array}$ & -1.86827 & 0.21461 & 0.01283 & 0.0138 & -0.06311 & \\
\hline $\begin{array}{c}\text { Fagus } \\
\text { sylvatica }\end{array}$ & NT & $\mathrm{dm}^{3}$ & $\mathrm{~cm}$ & $\mathrm{~m}$ & $\mathrm{D}^{\mathrm{a}} \cdot \mathrm{H}^{\mathrm{b}} \cdot \exp (\mathrm{c})$ & 1.55448 & 1.5588 & -3.57875 & & & \\
\hline $\begin{array}{l}\text { Fraxinus } \\
\text { excelsior }\end{array}$ & NT & $\mathrm{dm}^{3}$ & $\mathrm{~cm}$ & $\mathrm{~m}$ & $\mathrm{D}^{\mathrm{a}} \cdot \mathrm{H}^{\mathrm{b}} \cdot \exp (\mathrm{c})$ & 1.95277 & 0.77206 & -2.48079 & & & \\
\hline $\begin{array}{l}\text { Picea } \\
\text { abies }\end{array}$ & GER & $\mathrm{m}^{3}$ & $\mathrm{~m}$ & $\mathrm{~m}$ & $\mathrm{a} \cdot \mathrm{H} \cdot \mathrm{D}^{2}$ & 0.502 & & & & & \\
\hline $\begin{array}{c}\text { Pinus } \\
\text { sylvestris }\end{array}$ & GER & $\mathrm{m}^{3}$ & $\mathrm{~cm}$ & $\mathrm{~m}$ & $\mathrm{a} \cdot \mathrm{D}^{\mathrm{b}} \cdot \mathrm{H}^{\mathrm{c}}$ & 0.000056537 & 1.960466 & 0.894433 & & & \\
\hline
\end{tabular}


Table A1. Cont.

\begin{tabular}{|c|c|c|c|c|c|c|c|c|c|c|c|}
\hline \multirow[t]{2}{*}{$\begin{array}{c}\text { Tree } \\
\text { Species }\end{array}$} & & \multicolumn{3}{|c|}{ Unit } & \multirow[t]{2}{*}{ Equation } & \multicolumn{6}{|c|}{ Parameters } \\
\hline & & $\mathbf{V}$ & D & $\mathbf{H}$ & & $\mathbf{a}$ & $\mathbf{b}$ & c & d & e & $\mathrm{f}$ \\
\hline $\begin{array}{l}\text { Populus } \\
\text { spp. }\end{array}$ & NT & $\mathrm{dm}^{3}$ & $\mathrm{~mm}$ & $\mathrm{~m}$ & $\mathrm{a} \cdot \mathrm{D}^{(\mathrm{b}+\mathrm{c})} \cdot \mathrm{H}^{\mathrm{d}}$ & 0.0009507 & 1.895629295 & 0.001650837 & 0.8392146 & & \\
\hline $\begin{array}{l}\text { Prunus } \\
\text { avium }\end{array}$ & $\mathrm{BE}$ & $\mathrm{m}^{3}$ & $\mathrm{~cm}$ & $\mathrm{~m}$ & $\begin{array}{c}a+b \cdot D+c \cdot D^{2}+d \cdot D^{3} \\
+e \cdot H+f \cdot D^{2} \cdot H\end{array}$ & -0.002311 & -0.00117728 & 0.000149061 & $\begin{array}{c}-7.8058 \times \\
10^{-6}\end{array}$ & 0.00033282 & 0.000031526 \\
\hline $\begin{array}{l}\text { Quercus } \\
\text { robur }\end{array}$ & NT & $\mathrm{dm}^{3}$ & $\mathrm{~cm}$ & $\mathrm{~m}$ & $\mathrm{D}^{\mathrm{a}} \cdot \mathrm{H}^{\mathrm{b}} \cdot \exp (\mathrm{c})$ & 2.00333 & 0.85925 & -2.86353 & & & \\
\hline $\begin{array}{l}\text { Ulmus } \\
\text { spp. }\end{array}$ & NT & $\mathrm{dm}^{3}$ & $\mathrm{~cm}$ & $\mathrm{~m}$ & $D^{a} \cdot H^{b} \cdot \exp (c)$ & 1.942950 & 1.292290 & -4.200640 & & & \\
\hline
\end{tabular}

Table A2. Specific wood densities for tree species inventoried in the HF forests of the middle Elbe and sourced from the global wood density database [36].

\begin{tabular}{cc}
\hline Tree Species & Specific Wood Density $\left(\mathbf{g ~ c m}^{-3}\right)$ \\
\hline Acer spp. & 0.525 \\
Alnus glutinosa & 0.439 \\
Betula pendula & 0.525 \\
Carpinus betulus & 0.706 \\
Corylus avellana & 0.517 \\
Fagus sylvatica & 0.585 \\
Fraxinus excelsior & 0.560 \\
Picea abies & 0.370 \\
Pinus sylvestris & 0.422 \\
Populus alba & 0.353 \\
Prunus avium & 0.474 \\
Quercus robur & 0.560 \\
Ulmus spp. & 0.551 \\
\hline
\end{tabular}

Table A3. Mean ( \pm SE, $n=5)$, minimum and maximum carbon stocks of old hardwood floodplain forests on the active floodplain with different ages and forest structures. The total carbon stock combines five carbon pools: The above-and belowground carbon stocks (AGC and BGC) of trees, shrubs, and standing dead trees (SDT) $\geq 5 \mathrm{~cm}$ diameter at breast height, as well as coarse woody debris (DWD) and litter. The mean, standard error of the mean (SE), minimum (min), and maximum (max) values are shown for the five replicate plots per forest type. All carbon stocks are presented in Megagrams carbon per hectare $\left(\mathrm{Mg} \mathrm{ha}^{-1}\right)$.

\begin{tabular}{cccccccc}
\hline \multicolumn{2}{c}{\begin{tabular}{c} 
Forest Age and \\
\multicolumn{2}{c}{ Structure }
\end{tabular}} & $\begin{array}{c}\text { Total C } \\
\text { Stock }\end{array}$ & Tree & Shrub & SDT & DWD & Litter \\
\hline \multirow{2}{*}{$\begin{array}{c}\text { Young } \\
\text { planta- }\end{array}$} & Mean & 50.2 & 42.9 & 0.9 & 1.3 & 1.8 & 3.3 \\
tion & ME & 10.8 & 10.4 & 0.8 & 0.5 & 0.7 & 0.6 \\
& Max & 29.2 & 19.6 & 0.0 & 0.0 & 0.4 & 1.9 \\
\hline \multirow{2}{*}{ Old } & 88.2 & 77.7 & 4.0 & 2.8 & 3.6 & 5.0 \\
dense & Mean & 140.6 & 108.6 & 3.2 & 14.3 & 11.8 & 2.8 \\
& SE & 11.6 & 8.8 & 1.3 & 7.1 & 3.3 & 0.4 \\
& Min & 116.2 & 82.6 & 0.8 & 0.0 & 5.6 & 1.8 \\
Old & Mean & 181.8 & 133.6 & 7.9 & 32.9 & 22.1 & 4.0 \\
sparse & SE & 180.4 & 139.9 & 4.0 & 26.9 & 7.2 & 2.4 \\
& Min & 140.1 & 109.0 & 0.0 & 3.4 & 1.7 & 0.5 \\
\hline
\end{tabular}


Table A4. Mean $( \pm \mathrm{SE}, n=5)$, minimum and maximum carbon stocks of old hardwood floodplain forests at different hydrological conditions. The total carbon stock combines five carbon pools: The above-and belowground carbon stocks (AGC and BGC) of trees, shrubs, and standing dead trees $\geq 5 \mathrm{~cm}$ diameter at breast height, as well as dead woody debris and litter. The mean, standard error of the mean (SE), minimum ( $\mathrm{min}$ ), and maximum (max) values are shown for the five replicate plots per hydrological condition. All carbon stocks are presented in megagrams carbon per hectare $\left(\mathrm{Mg} \mathrm{ha}^{-1}\right)$.

\begin{tabular}{|c|c|c|c|c|c|c|c|}
\hline \multicolumn{2}{|c|}{ Hydrological Condition } & \multirow{2}{*}{$\begin{array}{c}\text { Total C } \\
\text { Stock }\end{array}$} & \multirow{2}{*}{$\begin{array}{c}\text { Tree } \\
108.6\end{array}$} & \multirow{2}{*}{$\begin{array}{c}\text { Shrub } \\
3.2\end{array}$} & \multirow{2}{*}{$\begin{array}{l}\text { SDT } \\
14.3\end{array}$} & \multirow{2}{*}{$\begin{array}{c}\text { DWD } \\
11.8\end{array}$} & \multirow{2}{*}{$\begin{array}{c}\text { Litter } \\
2.8\end{array}$} \\
\hline \multirow{4}{*}{ Low active floodplain } & Mean & & & & & & \\
\hline & SE & 11.6 & 8.8 & 1.3 & 7.1 & 3.3 & 0.4 \\
\hline & Min & 116.2 & 82.6 & 0.8 & 0.0 & 5.6 & 1.8 \\
\hline & Max & 181.8 & 133.6 & 7.9 & 32.9 & 22.1 & 4.0 \\
\hline \multirow{4}{*}{ High active floodplain } & Mean & 163.5 & 127.7 & 5.7 & 17.6 & 9.7 & 2.8 \\
\hline & SE & 8.3 & 8.7 & 2.0 & 13.0 & 5.3 & 0.3 \\
\hline & Min & 140.0 & 104.4 & 2.6 & 0.0 & 0.8 & 2.4 \\
\hline & Max & 185.1 & 151.8 & 12.6 & 68.2 & 29.7 & 3.8 \\
\hline \multirow{4}{*}{ Seepage water zone } & Mean & 145.3 & 130.3 & 2.6 & 3.0 & 5.0 & 4.4 \\
\hline & SE & 11.8 & 14.7 & 1.1 & 1.6 & 1.9 & 0.3 \\
\hline & Min & 124.4 & 104.5 & 0.0 & 0.0 & 0.4 & 3.9 \\
\hline & Max & 190.0 & 184.1 & 5.5 & 8.7 & 10.9 & 5.5 \\
\hline \multirow{4}{*}{ Tributary } & Mean & 146.5 & 127.1 & 0.7 & 6.3 & 8.2 & 4.2 \\
\hline & SE & 20.4 & 18.4 & 0.7 & 1.6 & 3.9 & 0.8 \\
\hline & Min & 88.5 & 78.1 & 0.0 & 0.4 & 2.3 & 2.2 \\
\hline & Max & 189.0 & 168.4 & 3.4 & 10.4 & 23.4 & 6.0 \\
\hline
\end{tabular}

\section{References}

1. Brown, A.G.; Harper, D.; Peterken, G.F. European Floodplain Forests: Structure, Functioning and Management. Glob. Ecol. Biogeogr. Lett. 1997, 6, 169-178. [CrossRef]

2. Sutfin, N.A.; Wohl, E.E.; Dwire, K.A. Banking carbon: A review of organic carbon storage and physical factors influencing retention in floodplains and riparian ecosystems. Earth Surf. Process. Landf. 2016, 41, 38-60. [CrossRef]

3. Dybala, K.E.; Matzek, V.; Gardali, T.; Seavy, N.E. Carbon sequestration in riparian forests: A global synthesis and meta-analysis. Glob. Chang. Biol 2019, 25, 57-67. [CrossRef]

4. BMU. Auenzustandsbericht: Flussauen in Deutschland; Bundesministerium für Umwelt, Naturschutz und Reaktorsicherheit (BMU), Bundesamt für Naturschutz (BfN): Berlin, Germany, 2009.

5. Brunotte, E.; Dister, E.; Günther-Diringer, D.; Koenzen, U.; Mehl, D. Flussauen in Deutschland-Erfassung und Bewertung des Auenzustandes. Nat. Und Biol. Vielfalt 2009, 87, 141.

6. Scholz, M.; Mehl, D.; Schulz-Zunkl, C.; Kasperidus, H.D.; Born, W.; Henle, K. Ökosystemfunktionen von Flussauen-Analyse und Bewertung von Hochwasserretention, Nährstoffrückhalt, Kohlenstoffvorrat, Treibhausgasemissionen und Habitatfunktion. Nat. Und Biol. Vielfalt 2012, 124, 258.

7. Naiman, R.J.; Decamps, H.; McClain, M.E. Riparia: Ecology, Conservation, and Management of Streamside Communities; Elsevier Academic Press: London, UK, 2005.

8. Griscom, B.W.; Adams, J.; Ellis, P.W.; Houghton, R.A.; Lomax, G.; Miteva, D.A.; Schlesinger, W.H.; Shoch, D.; Siikamaki, J.V.; Smith, P.; et al. Natural climate solutions. Proc. Natl. Acad. Sci. USA 2017, 114, 11645-11650. [CrossRef] [PubMed]

9. Dave, R.; Saint-Laurent, C.; Murray, L.; Daldegan, G.A.; Brouwer, R.; Scaramuzza, C.A.d.M.; Raes, L.; Simonit, S.; Catapan, M.; Contreras, G.G.; et al. Second Bonn Challenge Progress Report. Application of the Barometer in 2018; IUCN: Gland, Switzerland, 2019.

10. Hornung, L.K.; Podschun, S.A.; Pusch, M. Linking ecosystem services and measures in river and floodplain management. Ecosyst. People 2019, 15, 214-231. [CrossRef]

11. Thomas, H.; Nisbet, T.R. An assessment of the impact of floodplain woodland on flood flows. Water Environ. J. 2007, 21, 114-126. [CrossRef]

12. Dixon, S.J.; Sear, D.A.; Odoni, N.A.; Sykes, T.; Lane, S.N. The effects of river restoration on catchment scale flood risk and flood hydrology. Earth Surf. Process. Landf. 2016, 41, 997-1008. [CrossRef]

13. Leyer, I.; Mosner, E.; Lehmann, B. Managing floodplain-forest restoration in European river landscapes combining ecological and flood-protection issues. Ecol. Appl. 2012, 22, 240-249. [CrossRef] [PubMed]

14. Mckenney, R.; Jacobson, R.B.; Wertheimer, R.C. Woody Vegetation and Channel Morphogenesis in Low-Gradient, Gravel-Bed Streams in the Ozark Plateaus, Missouri and Arkansas. Geomorphology 1995, 13, 175-198. [CrossRef] 
15. Antonarakis, A.S.; Milan, D.J. Uncertainty in Parameterizing Floodplain Forest Friction for Natural Flood Management, Using Remote Sensing. Remote Sens. 2020, 12, 1799. [CrossRef]

16. Bennett, E.M.; Peterson, G.D.; Gordon, L.J. Understanding relationships among multiple ecosystem services. Ecol. Lett. 2009, 12, 1394-1404. [CrossRef] [PubMed]

17. Cierjacks, A.; Kleinschmit, B.; Babinsky, M.; Kleinschroth, F.; Markert, A.; Menzel, M.; Ziechmann, U.; Schiller, T.; Graf, M.; Lang, F. Carbon stocks of soil and vegetation on Danubian floodplains. J. Plant. Nutr. Soil Sci. 2010, 173, 644-653. [CrossRef]

18. Rieger, I.; Lang, F.; Kleinschmit, B.; Kowarik, I.; Cierjacks, A. Fine root and aboveground carbon stocks in riparian forests: The roles of diking and environmental gradients. Plant Soil 2013, 370, 497-509. [CrossRef]

19. Pretzsch, H. Forest Dynamics, Growth, and Yield; Springer: Berlin/Heidelberg, Germany, 2009; pp. 1-39. [CrossRef]

20. Thom, D.; Keeton, W.S. Stand structure drives disparities in carbon storage in northern hardwood-conifer forests. For. Ecol. Manag. 2019, 442, 10-20. [CrossRef]

21. Assman, E. The Principles of Forest Yield Study. Section D-Structure, Increment and Yield of Stands in Relation to Sivicultural Treatment; Pergamon: Oxford, UK, 1970; pp. 207-433. [CrossRef]

22. Schulze, E.D.; Beck, E.; Buchmann, N.; Clemens, S.; Müller-Hohenstein, K.; Scherer-Lorenzen, M. Plant Ecology, 2nd ed.; Springer: Berlin/Heidelberg, Germany, 2019. [CrossRef]

23. Bergmeier, E.; Roellig, M. Diversity, threats and conservation of European wood-pastures. In European Wood-Pastures in Transition; Routledge: London, UK, 2014. [CrossRef]

24. Schindler, S.; O’Neill, F.H.; Biró, M.; Damm, C.; Gasso, V.; Kanka, R.; van der Sluis, T.; Krug, A.; Lauwaars, S.G.; Sebesvari, Z.; et al. Multifunctional floodplain management and biodiversity effects: A knowledge synthesis for six European countries. Biodivers. Conserv. 2016, 25, 1349-1382. [CrossRef]

25. Reichardt, K.; Timm, L.C. Soil, Plant and Atmosphere: Concepts, Processes and Applications; Springer Nature: Cham, Switzerland, 2020.

26. Schwartz, R.; Gröngröft, A.; Miehlich, G. Pore Water Composition as Device for the Detection of Origin and Flow Direction of Soil Water in Alluvial Soils of the Middle Elbe River. Acta Hydrochim. Hydrobiol. 2003, 31, 423-435. [CrossRef]

27. European Commission. Interpretation Manual of European Union Habitats-EUR28; European Commission: Brussels, Belgium, 2013.

28. Parelle, J.; Brendel, O.; Bodénès, C.; Berveiller, D.; Dizengremel, P.; Jolivet, Y.; Dreyer, E. Differences in morphological and physiological responses to water-logging between two sympatric oak species (Quercus petraea [Matt.] Liebl., Quercus robur L.). Ann. For. Sci. 2006, 63, 849-859. [CrossRef]

29. Li, M.; Lopez, R.; Venturas, M.; Pita, P.; Gordaliza, G.G.; Gil, L.; Rodriguez-Calcerrada, J. Greater resistance to flooding of seedlings of Ulmus laevis than Ulmus minor is related to the maintenance of a more positive carbon balance. Trees-Struct. Funct. 2015, 29, 835-848. [CrossRef]

30. Urli, M.; Lamy, J.B.; Sin, F.; Burlett, R.; Delzon, S.; Porte, A.J. The high vulnerability of Quercus robur to drought at its southern margin paves the way for Quercus ilex. Plant. Ecol. 2015, 216, 177-187. [CrossRef]

31. Venturas, M.; Lopez, R.; Gasco, A.; Gil, L. Hydraulic properties of European elms: Xylem safety-efficiency tradeoff and species distribution in the Iberian Peninsula. Trees-Struct. Funct. 2013, 27, 1691-1701. [CrossRef]

32. DWD Climate Data Center (CDC). Multi-Annual Station Means for the Climate Normal Reference Period 1981-2010, f.c.s.l.a.f.r.s.l., Version V0.x; CDC: Atlanta, GA, USA, 2020.

33. Leyer, I. Effects of dykes on plant species composition in a large lowland river floodplain. River Res. Appl. 2004, 20, 813-827. [CrossRef]

34. Weber, A.; Hatz, M.; Rosenzweig, S. Hyd1d \& hydflood-R packages for the computation of 1D water levels, flood extents and flood duration along German federal waterways Elbe and Rhine. German Federal Institute of Hydrology (BfG): Koblenz, Germany, Unpublished BfG report. 2020.

35. Zianis, D.; Muukkonen, P.; Mäkipää, R.; Maurizio, M. Biomass and Stem Volume Equations for Tree Species in Europe. Silva Fenn. 2005, 4, 1-63.

36. Zanne, A.E.; Lopez-Gonzalez, G.; Coomes, D.A.; Ilic, J.; Jansen, S.; Lewis, S.L.; Miller, R.B.; Swenson, N.G.; Wiemann, M.C.; Chave, J. Data from: Towards a worldwide wood economics spectrum. Dryad Data Repos. 2009. [CrossRef]

37. UNFCCC. Measurements for Estimation of Carbon Stocks in Afforestation and Reforestation Project Activities under the Clean Development Mechanism: A Field Manual; UNFCCC: Bonn, Germany, 2015.

38. Mokany, K.; Raison, R.J.; Prokushkin, A.S. Critical analysis of root: Shoot ratios in terrestrial biomes. Glob. Chang. Biol. 2006, 12, 84-96. [CrossRef]

39. Böhl, J.; Brändli, U.B. Deadwood volume assessment in the third Swiss National Forest Inventory: Methods and first results. Eur. J. For. Res. 2007, 126, 449-457. [CrossRef]

40. Keeton, W.S.; Kraft, C.E.; Warren, D.R. Mature and old-growth riparian forests: Structure, dynamics, and effects on Adirondack stream habitats. Ecol. Appl. 2007, 17, 852-868. [CrossRef] [PubMed]

41. Applequist, M.B. A simple pith locator for use with off-centre increment cores. J. For. 1958, 56, 141.

42. Horner, G.J.; Baker, P.J.; Mac Nally, R.; Cunningham, S.C.; Thomson, J.R.; Hamilton, F. Forest structure, habitat and carbon benefits from thinning floodplain forests: Managing early stand density makes a difference. For. Ecol. Manag. 2010, 259, 286-293. [CrossRef] 
43. Junk, W.; Bayley, P.B.; Sparks, R.E. The flood pulse concept in river-floodplain systems. Dodge Ed. Proc. Int. Large River Symp. Can. Spec. Publ. Fish. Aquat. Sci. 1989, 106, 110-127.

44. Hesse, C.; Krysanova, V. Modeling Climate and Management Change Impacts on Water Quality and In-Stream Processes in the Elbe River Basin. Water 2016, 8, 40. [CrossRef]

45. Huang, S.C.; Krysanova, V.; Hattermann, F. Projections of climate change impacts on floods and droughts in Germany using an ensemble of climate change scenarios. Reg. Environ. Chang. 2015, 15, 461-473. [CrossRef]

46. Barkmann, T.; Siebert, R.; Lange, A. Land-use experts' perception of regional climate change: An empirical analysis from the North German Plain. Clim. Chang. 2017, 144, 287-301. [CrossRef]

47. Heklau, H.; Jetschke, G.; Bruelheide, H.; Seidler, G.; Haider, S. Species-specific responses of wood growth to flooding and climate in floodplain forests in Central Germany. Iforest-Biogeosci. For. 2019, 12, 226-236. [CrossRef]

48. Dieter, M.; Elsasser, P. Carbon Stocks and Carbon Stock Changes in the Tree Biomass of Germany's Forests. Kohlenstoffvorrate und -veranderungen in der Biomasse der Waldbaume in Deutschland. Forstwiss. Cent. 2002, 121, 195-210. [CrossRef]

49. Förster, A.; Culmsee, H.; Leuschner, C. Thinned northern German Scots pine forests have a low carbon storage and uptake potential in comparison to naturally developing beech forests. For. Ecol. Manag. 2021, 479. [CrossRef]

50. Wellbrock, N.; Grüneberg, E.; Riedel, T.; Polley, H. Carbon stocks in tree biomass and soils of German forests. Cent. Eur. For. J. 2017, 63, 105-112. [CrossRef]

51. Gschwantner, T.; Lanz, A.; Vidal, C.; Bosela, M.; Cosmo, L.; Fridman, J.; Gasparini, P.; Kuliesis, A.; Tomter, S.; Schadauer, K. Comparison of methods used in European National Forest Inventories for the estimation of volume increment: Towards harmonisation. Ann. For. Sci. 2016, 73, 807-821. [CrossRef]

52. Giese, L.A.; Aust, W.M.; Trettin, C.C.; Kolka, R.K. Spatial and temporal patterns of carbon storage and species richness in three South Carolina coastal plain riparian forests. Ecol. Eng. 2000, 15, S157-S170. [CrossRef]

53. Schöngart, J.; Arieira, J.; Felfili Fortes, C.; Cezarine de Arruda, E.; Nunes da Cunha, C. Age-related and stand-wise estimates of carbon stocks and sequestration in the aboveground coarse wood biomass of wetland forests in the northern Pantanal, Brazil. Biogeosciences 2011, 8, 3407-3421. [CrossRef]

54. Keeton, W.S.; Whitman, A.A.; McGee, G.C.; Goodale, C.L. Late-Successional Biomass Development in Northern HardwoodConifer Forests of the Northeastern United States. For. Sci. 2011, 57, 489-505. [CrossRef]

55. van Breugel, M.; Ransijn, J.; Craven, D.; Bongers, F.; Hall, J.S. Estimating carbon stock in secondary forests: Decisions and uncertainties associated with allometric biomass models. For. Ecol. Manag. 2011, 262, 1648-1657. [CrossRef]

56. Glaeser, J.; Schmidt, P.A. Zur historischen Entwicklung des Baumartenbestandes von Hartholz-Auenwäldern—Dargestellt am Beispiel des Leipziger Auenwaldes. Allgem. For. Jagdztg. 2006, 178, 90-97.

57. Larsen, J.B. Ecological Stability of Forests and Sustainable Silviculture. For. Ecol. Manag. 1995, 73, 85-96. [CrossRef]

58. Pretzsch, H.; Bielak, K.; Block, J.; Bruchwald, A.; Dieler, J.; Ehrhart, H.P.; Kohnle, U.; Nagel, J.; Spellmann, H.; Zasada, M.; et al. Productivity of mixed versus pure stands of oak (Quercus petraea (Matt.) Liebl. and Quercus robur L.) and European beech (Fagus sylvatica L.) along an ecological gradient. Eur. J. For. Res. 2013, 132, 263-280. [CrossRef]

59. Ma, Z.L.; Chen, H.Y.H.; Bork, E.W.; Carlyle, C.N.; Chang, S.X. Carbon accumulation in agroforestry systems is affected by tree species diversity, age and regional climate: A global meta-analysis. Glob. Ecol. Biogeogr. 2020, 29, 1817-1828. [CrossRef]

60. Guyot, V.; Jactel, H.; Imbaud, B.; Burnel, L.; Castagneyrol, B.; Heinz, W.; Deconchat, M.; Vialatte, A. Tree diversity drives associational resistance to herbivory at both forest edge and interior. Ecol. Evol. 2019, 9, 9040-9051. [CrossRef] [PubMed]

61. Erfmeier, A.; Haldan, K.L.; Beckmann, L.M.; Behrens, M.; Rotert, J.; Schrautzer, J. Ash Dieback and Its Impact in Near-Natural Forest Remnants-A Plant Community-Based Inventory. Front. Plant. Sci. 2019, 10, 658. [CrossRef] [PubMed] 